\title{
Constructions of surrogates, egg donors, and mothers: Swedish gay fathers' narratives
}

Feminism \& Psychology

0 (0) $1-20$

(C) The Author(s) 2020

(c) (i)

Article reuse guidelines: sagepub.com/journals-permissions DOI: I0.II77/09593535209224I5

journals.sagepub.com/home/fap

\author{
Anna Malmquist (D) and \\ Sonja Höjerström \\ Linköping University, Sweden
}

\begin{abstract}
The study explored in detail how Swedish gay fathers (through surrogacy) talked about the surrogate mother and the egg donor. Thirteen semi-structured interviews with 22 gay fathers were conducted and analysed using critical discursive analysis. The surrogates were primarily constructed as a close family member, but occasionally in terms of their instrumental function. They were often described as active and independent, but occasionally as vulnerable or exploited. The egg donors were in some interviews constructed as close family members, while others talked about them as distant acquaintances. Further, donors were constructed either as a significant individual (for the fathers), or as an instrumental provider of the oocyte. While some participants constructed the surrogate and/or donor as their child's mother(s), others were more reluctant or ambivalent about the mother construct. In conclusion, the participants engaged in rhetorical work that shed a positive light on surrogacy, and their own decisions were depicted as solid, ethical and genuine. The participants' positive framing can be understood as the production of a counter discourse, in relation to an ongoing debate in Sweden, in which surrogacy is constructed as exploitation, dehumanization and prostitution.
\end{abstract}

\section{Keywords}

gay fathers, surrogacy, egg donation, motherhood, fatherhood

\section{Corresponding author:}

Anna Malmquist, Department of Behavioural Sciences and Learning, Linköping University, SE-58। 83 Linköping, Sweden.

Email: anna.malmquist@liu.se 
When two men in an intimate relationship want to have children together, surrogacy is one option (Carneiro, Tasker, Salinas-Quiroz, Leal, \& Costa, 2017). In a surrogacy arrangement, a person with child-bearing capacity agrees to carry the pregnancy for the intended parents. The surrogate (sometimes labelled surrogate mother) may use her ${ }^{1}$ own egg, in a so-called traditional surrogacy. More commonly, the oocyte is provided by a separate donor, to make a gestational surrogacy. In the case of gay male couples, sperm is usually taken from one of the partners. Once born, the child is passed to the intended parents, who raise the child from that point forward.

Previous research shows variation regarding the kind of relationship that develops between the new families and the women involved in the creation of the child (Blake et al., 2016; Carone et al., 2018; Jadva, Gamble, Prosser, \& Imrie, 2019; Teman, 2010). While some continue their relationship with the surrogate for years, others terminate it shortly after birth. Some egg donors also stay in contact with the family, while others are anonymous to them. Regardless of what kind of relationship they form (or do not form), the parents must relate to the surrogate and donor in their narratives about how they became a family, and in response to people's - and their own children's - queries. The present article draws on interviews with 22 Swedish gay fathers through surrogacy, and focuses on how they talked about the surrogate and the egg donor. We have analysed in detail how the interviewees depicted the surrogate and the egg donor. Before engaging with the interview data, we will provide an overview of previous research on gay fatherhood through surrogacy and egg donation, followed by a picture of an ongoing debate on the ethics in surrogacy. Thereafter, we describe gay fatherhood in contemporary Sweden.

\section{Gay fatherhood through surrogacy and egg donation}

Gay fatherhood has increasingly gained the attention of researchers (for an overview see Carneiro et al., 2017). Studies in the field are almost exclusively conducted in Western countries, with a majority from the United States. They have covered a range of topics, including pathways to parenthood, parenting experiences, and children's psychological adjustment. A number of studies concern gay men who became fathers through surrogacy and egg donation. Reasons for choosing surrogacy over other options often include a combination of what is legally and practically accessible, with desires such as becoming genetic parents or raising a child from infancy (Blake et al., 2017; Ziv \& Freund-Eschar, 2015). Due to high costs, most parents who use surrogacy have high incomes (Jadva et al., 2019). A few studies have focused on the parents' and child's relation with the donor and surrogate after birth (Blake et al., 2016; Carone et al., 2018, Jadva et al., 2019). In their study on domestic surrogacy in the United States, Blake and colleagues (2016) showed that a vast majority kept in touch with the surrogate. Most described the relationship as positive, but seldom as close. Likewise, Carone and colleagues (2018) described how most of their Italian participants kept in touch 
with American surrogates, generally through Facebook or email. Fewer stayed in touch with egg donors, but when there was a continuous relationship, it was generally framed as positive. A British study showed that parents were in more frequent contact with surrogates from the UK and USA, compared to surrogates from Asia (Jadva et al., 2019).

A related area of research concerns the surrogates' and egg donors' situation. A research overview showed that a vast majority of surrogates are in good psychological health after birth and in the long term (Söderström-Anttila et al., 2016). Most were happy with their surrogacy experience, and relations with the parents and child were often positive. An interview study with Israeli and US surrogates described the women as committed to their assignment, forming close relationships with the intended parents (Teman \& Berend, 2018). While being happy for the children, they did not see themselves as their mother, rather as an aunt. Similarly, a study of egg donors in the United States showed that most were happy about the donation (Jadva, Freeman, Kramer, \& Golombok, 2010). The study concerned egg donors who had actively sought contact with their offspring through a registry, showing that those who had contact with their offspring generally felt positive about the relationship, while some anonymous donors were unhappy with the lack of contact. In contrast, another study of egg donors in the United States showed that many were happy with being anonymous (De Melo-Martín, Rubin, \& Cholst, 2018).

\section{Surrogacy - a debated path to parenthood}

Ethical concerns regarding surrogacy have been debated by feminist scholars the past decades, and have developed during the second and third waves of feminism (Thompson, 2005). While some scholars argue that surrogacy can be arranged under fair conditions (Humbyrd, 2009), others raise sharp criticism. A recent summary of feminist critiques described three main concerns: that women's bodies are exploited, that women's and children's bodies are commodified, and that parenthood becomes a result of (unequal) consumption (Stuvøy, 2018). Several scholars have objected to surrogate arrangements, arguing that women's bodies are exploited (Ventura, Rodríguez-Polo, \& Roca-Cuberes, 2019; Wilkinson, 2003). They argue that surrogacy is harmful for the surrogates, due to the general risks of pregnancy and the potentially stressful experience of being separated from the infant after birth (Johansson Agnafors, 2014). Further, critics have argued that surrogacy commodifies (poor) women's bodies and the babies born as a result of the arrangements (Ventura et al., 2019). The commercialization of parenthood has also been problematized in relation to global inequalities. As put by Mamo (2018, p. 27), we today see "multidirectional transnational flows of global assisted reproduction where labour is called upon to support life in one place at the potential expense of the lives in another".

In Sweden, the increasing number of transnational surrogacy arrangements has been a topic of several television and radio documentaries, where surrogacy has 
generally been depicted as exploitation of poor women, who are said to be utilized in "baby factories" for the means of resolving rich people's involuntary childlessness (e.g. Collmar, 2017; Uppdrag granskning, 2018). Initiated by a book written in 2010 (Ekis Ekman, 2010), in which the feminist author compared surrogacy to prostitution, several women and feminist organizations have declared their disapproval of surrogacy (e.g. Åström, 2011). Other debaters and organizations, such as the largest LGBTQ association in Sweden, have argued for legislation permitting so-called altruistic surrogacy, i.e. when the surrogate mother does not receive any payment for the duty itself (e.g. Zettergren, 2011). A public investigation was initiated to investigate the possibilities of legalizing altruistic surrogacy in Sweden, but in the end the investigation suggested that surrogacy should not be permitted by Swedish law, due to a fear of exploitation of women (SOU 2016:11). Swedish parents who have children through surrogacy must relate to the ongoing and often high-pitched debate (Arvidsson, Johnsdotter, \& Essén, 2015). In their interview study, Arvidsson and colleagues (2015) showed how parents navigate the debate through presenting their own choices as ethical and solid.

\section{Gay fatherhood in Sweden}

Several legislative changes in the past decades have improved the legal situation for same-sex couples and parents in Sweden, including the right to adoption in 2003 (Mägi \& Zimmerman, 2015). However, joint adoption has been very difficult to achieve for same-sex couples (Malmquist \& Spånberg Ekholm, 2020), and because lesbian couples gained access to fertility treatment with donated sperm in 2005 , fewer lesbian couples are willing to engage in shared parenting with gay men (Malmquist, 2016). At present, gay men generally face formidable obstacles when trying to start a family (Andreasson \& Johansson, 2017; Arvidsson, Johnsdotter, Emmelin, \& Essén, 2019; Malmquist \& Spånberg Ekholm, 2020).

Surrogacy arrangements are not allowed within Swedish healthcare (SOU 2016:11), but there are agencies that help couples and singles to carry out surrogacy pregnancies abroad. India was a common destination before that country banned foreign couples' surrogacy (Arvidsson et al., 2019; Sydsjö, Skoog Svanberg, \& Lampic, 2019). Currently, most Swedish gay couples turn to clinics in the United States. The procedure is expensive, and therefore only available to financially secure couples.

A traditional surrogacy, where the surrogate's own egg is used, may be achieved through home insemination. The involved parties can make a morally obligatory agreement, such as that the surrogate will not make any claims to the child, but such agreements are not legally binding in Sweden (Mägi \& Zimmerman, 2015). Regardless of whether it is a gestational or traditional surrogacy, the genetic father can be established as legal father. His partner can thereafter apply for secondparent adoption and share legal parenthood with his partner. 


\section{Aims}

While some previous studies focus on gay fathers' relations with egg donors and surrogates (Blake et al., 2016; Carone et al., 2018; Jadva et al., 2019), there is to our knowledge no previous study that focuses in detail on how gay fathers depict the surrogate and the egg donor when talking about their own families. We argue that such a focus adds to the understanding of how gay men perceive the reproductive labour that is generally carried out by women (going through a pregnancy and giving birth, or providing an oocyte that is removed after hormone stimulation of the ovaries). Further, it adds a picture of how gay men understand maternity, including their images of what a ("real") mother is, and what a mother is not. The aim of the present study is therefore to 1) analyse in detail how gay men who became fathers through surrogacy constructed the surrogate and the donor in their talk, and 2) analyse the discursive effects of these constructions.

\section{Method}

\section{Critical discursive psychology}

The present work draws on critical discursive psychology (CDP), which is a form of discourse analysis (Edley, 2001; Wiggins, 2017). In CDP the focus is on analysing how people in social interaction actively use different metaphors, images and ideas to present themselves and construct the world around them. Often, people use their accounts to depict themselves, their choices and their motives as sound, logical and reasonable. Talk is actively used to achieve such effects. Further, talk is oriented towards a recipient, and to whatever is at stake within the context of the conversation. In the present analysis, we analyse how our interviewees talked about surrogates and egg donors in the specific context of a research interview with a focus on their family narrative.

\section{Data collection}

The present study is part of a larger research project on Swedish gay men's fatherhood (Malmquist \& Spånberg Ekholm, 2020). In total, 30 gay fathers and 12 childless gay men were interviewed within the project. The present analysis is based on interviews with the participants who had become fathers through surrogacy. Most of them were interviewed together as a couple, while some participated without their partner. The analysis draws on 13 interviews with 22 participants.

Two interviews were initially conducted by Anna Malmquist in 2010, as part of a broader research project on same-sex parenting (Malmquist, 2015). These two were utilized as a pilot study when Malmquist applied for funding for a focused research project on gay father families in Sweden. This project was funded by Forte in 2017 and approved by the regional ethics board at Linköping University the same year. Additionally, 11 interviews with gay men who had become parents through surrogacy were conducted in 2018, by Sonja 
Höjerström and Alexander Spånberg Ekholm. The interviewers identify within the LGBTQ spectrum, but are not gay fathers themselves. Some interviewees asked about the interviewers' identification and/or family situation prior to the interview, while others did not. Such questions were answered openly.

Participants were primarily recruited through social media. A Facebook group for gay fathers, and the Swedish national association for homosexual, bisexual, transsexual and queer rights (RFSL) circulated the recruitment advertisement through their social media channels and websites. The researchers also shared the ad as open posts on their private Facebook walls. Snowball recruitment was also used. The ad informed briefly about the study, and asked interested couples to contact the researchers for more information. Interested people received an information letter by email and were then contacted by telephone or email to schedule an interview. The participants themselves were able to decide the location and time for the interview to facilitate participation, where possible.

The semi-structured interviews followed an interview guide covering topics such as the decision to parent, pathways to parenthood, relational aspects of parenting, and encounters with professionals at government agencies (e.g. when establishing legal fatherhood), healthcare, and preschool. All interviews were audio-recorded and were between 45 and 107 minutes long. Most of them were conducted in the interviewees' homes, and a few were conducted in public cafes. The interviewees were assured that they would remain anonymous, that they had the right to discontinue their participation at any time, and that they had the right to refuse to answer questions. They were also informed about the structure of the interview, the purpose of the study and in what form the results would be published. The interviewees gave their written informed consent to participate.

\section{Transcription and analysis}

All interviews were transcribed verbatim, with pseudonyms replacing names. The interviewees were given an opportunity to read their transcripts and, if they wanted, to have specific parts of the interview removed. A few interviewees took this opportunity.

As an initial analytical step, we read through all the interviews, and most of the data was coded and sorted thematically by Höjerström. For this study, all interview parts that concerned surrogates and egg donors were marked and selected to be analysed in detail. A first analysis of this selected data was conducted by Höjerström, who focused on the eight interviews that she and Spånberg Ekholm had conducted. The result of this analysis is presented in Höjerström's master's thesis (Höjerström, 2018). Later, Malmquist added the five interviews she had conducted, and developed the analysis further. The analytical procedure focused on identifying patterns in the interviewees' talk about surrogate and donor, respectively. We focused on how participants constructed objects and subjects in their accounts, and what terms and metaphors they used to present their narratives. Excerpts were selected to illustrate the findings. All excerpts were translated from 
Swedish to English by a professional, native English-speaking translator. The quality of the translations was checked by Malmquist, revisiting the original audio data.

\section{The participants and their families}

The 22 participants were between 33 and 52 years old, most of them in their forties. Ten couples resided in large Swedish cities, and two couples in middle-sized cities. Further, one couple lived in a small town in another western European country. A majority of the participants had a university education and a minority had exams equivalent to high school. Most participants were upper-middle-class men with high incomes. Most of them were born in Sweden, and most were white.

Eleven couples had made gestational surrogacy arrangements, ten through agencies in the United States, and one through an eastern European agency. All of them stayed in contact with the surrogates. One couple had an anonymous egg donor, while the remaining had open donors, whom they stayed in touch with. Two couples had children through traditional surrogacy, in which the surrogates used their own eggs. They had conceived through privately arranged home inseminations.

Most couples (8) had one child at the time of the interview, while the remaining five couples had two or three children. Two couples were expecting an additional child by the time of the interview. In total, six couples had experienced more than one pregnancy. All of them had chosen to have the same egg donor for all their children, while most had a different surrogate for the second pregnancy. The children were $0-7$ years old at the time of the interview, with a majority being 3 years or younger.

In the following, we present our analysis of how the interviewees talked about surrogates and egg donors, and how the concept of 'mother' was used in relation to surrogate and donor.

\section{Constructions of surrogates}

The surrogates were prominent figures in all the interviewees' narratives. In the following, we show how the fathers talked about the surrogates, how they depicted their role and function, and how they described their own and their children's relationship to them. Two types of narratives dominated this talk. First, surrogates were depicted as close friends or family members, with a close relationship to the fathers and children. Such depictions were sometimes "backed up" with concrete examples of how the friendship was performed (i.e. regular Skype contact), but the focus of the analysis is not on how the relationship was played out in everyday life, but on how the relationship was depicted by the fathers, and the discursive effects of this talk. Second, surrogates were depicted as active and independent women. Again, our analytical focus does not concern the actual characteristics of the surrogates but how they were depicted by the fathers. In contrast to the dominant 
narratives, a few instances in the data showed counter-narratives, in which the surrogate was constructed as having an instrumental function, rather than as a person in a significant relationship. Further, a few claims in the interviews constructed narratives in which the surrogate was presented as vulnerable or exploited.

\section{The surrogate as a close family member, or an instrumental function}

Most interviewees portrayed their relationship with the surrogate as close, warm and loving, and most interviewees drew on concepts related to kinship, family or friendship. In the excerpt below, Martin described their contact with the surrogate:

A wonderfully close contact developed, both with the surrogate mother but also with her husband and their family and [we] met them. They see us as their Swedish relatives, and [we] have socialized. We were invited to dinner with her parents, and our daughter was with the surrogate mother and her husband then, so they got the chance to be alone a bit.

Martin depicted strong bonds, as he emphasized their "wonderfully close contact". The close relationship not only involved the surrogate; he also included "her husband and their family" and "her parents" as their extended family. Martin further stressed the reciprocal aspect of the relationship, as he claimed that "They see us as their Swedish relatives". Such pictures of a warm, genuine, and long-lasting relationship appeared frequently in the data. In accordance with this, other interviewees described their surrogate with positive, complimentary characteristics, such as being "completely wonderful", or "fantastic". The recurrent constructions of surrogates as family members showed the interviewees' interest in including surrogates not only in their narrative of how they became parents, but in their very narrative of who their family is. The construction of the surrogate as a family member (rather than, for example, a helper) connotes a closeness and reciprocity where both parties are mutually reliant, and it de-emphasizes associations to the financial agreement and different roles of provider and purchaser of a duty. Describing a family or friendship bond (which may be honestly experienced) has discursive effects of providing a positive and loving narrative.

In contrast to the dominant narrative of close relations, a few examples in the data deviated from the pattern. In these, the surrogate was presented as a more distant figure, constructed more as having only an instrumental function rather than as a significant other. Göran explained how they had gone through several unsuccessful embryo transfers, and how egg donors and intended surrogates had been replaced throughout the process. When their child was finally born, they had not yet met the surrogate.

We hadn't met her. We met the first time, the first [intended] surrogate mother, but then when we changed surrogate mothers and egg donors so many times, it wasn't possible to (.) travel to [country in eastern Europe] every time (Interviewer: No). 
The surrogate mother is very important, but in purely bio-, biological terms, it's not her genes.

In this excerpt Göran presented it as unrealistic to travel several times to meet the intended surrogates they were matched with. The procedure of replacing the intended surrogates and donors after unsuccessful embryo transfers, was, however, not problematized in his account. This way of talking gives the impression of an instrumental function. Göran did claim that the "The surrogate mother is very important", but as he in the next breath stressed that "in purely bio-, biological terms, it's not her genes", the account rather functioned as a disclaimer for them not to form a close relation. In contrast to the dominant discourse where the surrogate is constructed as family, Göran's account has the opposite effect of "de-familizing" the surrogate; he emphasized that it was not her genes, and thereby constructed her as "not family". The account draws on a discourse where the surrogate is constructed as instrumental, important in her function, but not as a person or part of a relationship, a framing which works well to justify their decision to decline to meet the surrogate prior to the birth.

\section{The surrogate as strong and independent, or vulnerable and exploited}

A dominant pattern was to construct images of surrogates as active, independent and strong women. The interviewees stated that the women were proud of their decision to be a surrogate, and described how they had been committed and engaged throughout the process. Karl described their surrogate as a person in control of her situation:

The opinions on surrogacy that I seem to hear in the debate, or sometimes notice from various, um, are based mainly on [inaudible word] that the person carrying the child is always a victim, and that people are victims of structures and, yeah, but in different ways like that. (Interviewer: Mm). But, eh, Fabian's biological mother (.) um, is like, to me the opposite of all that, so she, she is like (laughs) she is very straight-forward and like, (Interviewer: Mm) that is, "My body, I love being pregnant" [...] she feels so, what's it called, in charge (Interviewer: $\mathrm{Mm}$ ) of her process.

Karl presented a picture of an independent woman, being "in charge of her process", a process he claimed she had engaged in because she "love[s] being pregnant". Most interviewees made similar claims about the women's motives for surrogacy; they said that the women loved being pregnant, or that they had a strong desire for doing a good deed, or both. A few interviewees acknowledged financial motives for surrogacy, but still framed the decision as an active choice made by women who were in charge of their situation. In Karl's excerpt, the image of the committed and strong woman was presented as "the opposite" of a dominant image of surrogates. Karl referred to the ongoing debate on surrogacy, where the discourse of exploited women is prominent. According to Karl, this image is "problematic". Likewise, 
several other interviewees explicitly dissociated their own process from the images of surrogacy that dominate the contemporary debate in Sweden. They explicitly distanced themselves from the idea that surrogates are by necessity exploited or victims. Some interviewees did acknowledge exploitation of poor women as part of surrogacy elsewhere, but their own processes were recurrently put forward as a contrast, as good examples of positive arrangements, with genuinely committed women. The framing of strong women (which may be genuinely experienced) has the discursive effect of distancing from the highly undesired image of exploitation.

However, the vulnerable or exploited surrogate can be traced in some of the interviewees' descriptions of their own processes as well. These are short glimpses, often describing their thoughts and feelings at the time that the infant and surrogate were separated. Olof and Jens elaborated on this, shortly after being asked how they remembered the birth of their daughter:

Olof: There was that really strange feeling of cutting the umbilical cord, because it was this (Jens: Yes, God, yes) like, ulti-, like, it was something "Now we're cutting the ties", that is, these tw- forty weeks that we have had together with Carol (Jens: Mm), we, we knew that it would continue, but somehow it was like "No, now we're cutting ties, like". (Interviewer: Mm.) [...] It was just "No, what should we do with her?". Because it was like "We can't leave Carol there", (Jens: No) "Go and enjoy your baby" she just said. (Jens: Yes, yes it was-) "But is it ok, shouldn't we stay with you?", (Jens: There were lots of emotions) But she was really "No, go now", like.

Jens: There were lots of emotions there. We had Vilde in a separate room and Carol was in her own, and we thought, "Should she be in there on her own?" She had, like, given birth to Vilde, "Wonder how she is?," it didn't feel good. (Olof: No) So we were in there and asked her how she was "Yes, but it's fine, it's no problem, my husband will be here soon and" oh, [sigh] sure, she had done this before, but like (.) but you still feel a responsibility, so. She had carried her, she has just- I mean that, that (.) that giving birth is like, we can't understand it of course, but it's like a, a traumatic and like, a (.) thing to do.

Olof and Jens expressed strong feelings in relation to separating their newborn child and the surrogate. Their description of a reluctance to leaving the surrogate alone in her own room after the delivery, and their framing of a delivery as something "traumatic", constructed an image of the surrogate as vulnerable, alone and exposed. At the same time, the couple presented themselves as responsible "you still feel a responsibility", both for her feelings and situation, "wonder how she is", and for putting her in that position to begin with. Their own position seemed ambivalent and guilty. At the same time, they emphasized how the surrogate had acted calm and confident in the situation. Thus, rather than presenting the surrogate as vulnerable, they expressed their worries about her potential vulnerability. Similar accounts appeared in several interviews, but often only as short passages, surrounded by the dominant discourses of strong, independent 
surrogates and grateful and committed parents. The short glimpses and tentative talk show how these experiences were difficult to address, possibly because they complicate the otherwise dominant picture of a happy and joyful experience.

\section{Constructions of egg donors}

In the following, we turn to the interviewees' talk about egg donors, how they depicted their role and function, and the fathers' and children's relationship to the donor. Most couples (11 of 13) had utilized a separate egg donor (i.e. not a surrogate's own egg). In relation to the surrogates, about whom the interviewees talked extensively, much less was said about egg donors. Two contradictory narratives form the interviewees' images of their relationship with donors; either the donor was presented as akin to a close family member, or as distant acquaintance. When talking about the donor's function, two other types of narratives were used. In one narrative, the donor was constructed as a significant individual, and in the other as an instrumental provider of genetic material.

\section{The donor as a close family member, or a distant acquaintance}

Some interviewees described a close relationship with the donor, who was presented as a close friend or family member. Such descriptions formed a narrative reminiscent of how the surrogate was presented. Anders had three children from the same donor:

The egg donor is a completely wonderful girl [. . .] who, er, we have met many times as well, though most people don't have any relationship with their egg donor, but we do, because we wanted that. Because- so that, when the twins were born, she and her mother drove for eight and a half hours to visit us (Interviewer: Wow!). And, er, were with us for almost one week, so, er, Sofia is five, was five then, so she has, like, gotten to know her mom (Interviewer: $\mathrm{Mm}$ ) who she calls "Mom" too (Interviewer: Mm). And that is fine (Interviewer: $\mathrm{Mm}$ ) but she understands that she [the donor] isn't part of our fam- that is, she is part of our family but at a good distance, like (Interviewer: $\mathrm{Mm})$. And that er, Linda who is her daughter is her half-sister, like, and... So we have a large (laugh) modern family.

In the excerpt, Anders depicted a committed relationship with the donor, who was presented with warm praise. Through the statement "because we wanted that", Anders made clear that the close relationship had been an active choice. Anders also described how the donor and her mother had travelled far to meet them, thus he stressed the reciprocity in the relationship. Thereafter, Anders rhetorically negotiated the donor's status as family member or not. First, he referred to the donor as his child's "mom", and added that this is how the child herself refers to the donor. Immediately after that, he seemed to hesitate and claimed that "she isn't part of our fam-", but in the next breath Anders concluded that "she is part of our family but at 
a good distance", and rhetorically solved the dilemma by depicting themselves as a "big modern family". Thus, as the family concept was extended, the donor was included in the family image. The rhetorical benefits of depicting egg donors as family may be similar to those of constructing surrogates as family (e.g. emphasizing closeness and reciprocity, detaching connotations to consumption and paid labour). However, in most interviews this framing does not dominate the talk about donors.

Unlike Anders, most interviewees framed the donor as a more distant person. They highlighted that the donor was much younger than themselves, and had different interests and lifestyle. Krister described a distant contact:

It was also important when choosing egg donor that she was also open to having an open relationship. There we ha- have a larger age difference between us and have also had a smaller amount of contact along the way [compared to the surrogate] which makes it much harder to [keep] that contact alive, er and there I don't have any Facebook contact [...] so there we have had more difficulty having a, like, a lasting relationship (Interviewer: $\mathrm{Mm}$ ) so now that relationship is down at the level where I sent or we send a Christmas card every year (Interviewer: Mm) just, so.

Krister and his partner had chosen an open donor, but he expressed a lack of interest and motivation for keeping in regular touch. In several other interviews, the relationship with the donor was not presented as important at the present, but rather as an option for the child in future. The donor was depicted as an important origin, something one might search for and have questions about. The donor's status as close friend or family seemed less urgent to emphasize. The framing of donor as origin rather than family corresponds well to how gamete donation is generally practised and understood in Sweden. Thus, the interviewees connect to a well-known discourse on egg donation.

\section{The donor as an individual, or as an instrumental provider}

When discussing how they selected the egg donor, the interviewees drew on two types of narratives. In one type, the donor was constructed as an individual whose motives for donating eggs were central. When drawing on this discourse, the interviewees stressed their desire for a donor whose motive was to do a good deed, and who was interested in ongoing contact. In the other type of narrative, the donor was depicted as more of an instrumental provider of genetic material. In these parts of the interviews, the focus was on selecting a donor with a desired appearance and a good medical heritage. Most often, both these discourses were drawn on alternately within the interviews, as in Jens' account, when he was asked what is important to consider when selecting a donor:

Then we think at least about (.) "How is her heritage?" Diseases, er [...] you select a few [donors] and Skype with them, but then you might already want to know the 
background and (Interviewer: $\mathrm{Mm}$ ) and that, how- if there is any heritage for, like, serious diseases and that, quite simply. That's how we thought (Olof: Yes, but, of course, it-), in combination with that it should be a pleasant person, and, and why does she want to do this, why does she want to contribute to being a donor? (Interviewer: $\mathrm{Mm}$ ) That was important. (Interviewer: Mm) Plus, plus it's (.) not, not a disadvantage that she is good looking, we figure.

Jens' point of departure in the excerpt was the donors' genetic heritage. Further, he drew on the discourse of an instrumental provider of genetic material as he claimed that a good appearance was "not a disadvantage". However, the other discourse was drawn on as well, as Jens stressed how they had asked for the donor's motives, and how they searched for a "pleasant person". Thus the donor was also selected based on her own personal motives and behaviour, not only for the genetic material she might pass on to their children. In Jens' account, the two discourses seem to function well together: they had searched for someone with good motives, who also would provide desirable genes. However, there is a tension between the discourses where the former constructs the donor as a subject (a person) and the latter as an object (genetic material).

While most interviewees described how they selected donors based (partly) on their heritage, several of them also stressed that they felt uncomfortable in doing so. Patrik was asked how they chose donor:

That was quite a strange process [...] you leaf through, previously it was a physical catalogue, now it's a database and that feels really weird it feels just as weird as buying a dog and choosing a dog breed, and even if that's a horrible comparison, it's really, really weird emotionally, so that at least I was very prepared for that, and had braced myself very much.

Patrik stated repeatedly how the process of selecting the donor felt "strange" and "really weird". He drew on the discourse of the donor as an instrumental provider, as he compared the donor choice with choosing a "dog breed", the donor appeared as a genetic material, important for her characteristics, but not as an individual. His comparison pinpointed the objectification of donors and the commercialization of donation. When framing the process as awkward, and his own comparison as "horrible", Patrik distanced from the discourse. At the same time, he showed an acceptance of the procedure, as he went through it with a mindset of being "braced". Thus, his account had the rhetoric effect of both problematizing and legitimizing objectification and commercialization.

\section{Constructions of mothers}

In this final part of the results section, we show how the participants used the word "mom/mother",, when talking about surrogates and donors. In most interviews, 
both surrogates and donors were alternately constructed as their child's mother and as a non-mother (that is, not "actual" or "real" mother).

\section{Surrogate and donor as mother, or not actual mother}

Most interviewees negotiated the word "mom/mother" in relation to both the surrogate and the donor. While most interviewees expressed an ambivalence about or reluctance to refer to them as their child's "mom", others used the word without much problematizing. Kent created a narrative where both the surrogate and the egg donor were constructed as moms:

We wanted to have two mom-, two moms in-, indirectly in our situation, then you never know how it en-, how it ends, but that, that was our aim in any case. We wanted to be able to say to our boys, "Here are your moms", we want to, like, be able to send a card, or a letter or email, or that they are able to do that. That is really important to us.

In this excerpt, Kent referred to both the surrogate and the egg donor as the children's "moms", but still marked the distance to them as he claimed that they are mothers "indirectly". While Kent was at ease and un-problematizing about the mother construct, several other interviewees negotiated the construct much more. Some negotiated whether it is the egg donor or the surrogate who should be considered "mom", or the "the real mom". The construction of the surrogate and/or the egg donor as mother(s) may have discursive benefits. It functions as a normalization of the gay father family, where the absence of a mother in daily life is compensated by the presence of the surrogate or donor as (distant) mother(s). Presenting the women involved in the procreation of the child as "mothers" also has the effect of depicting closeness and reciprocity and detaches the relations from less desired associations to commercialism, commodification and exploitation.

However, several interviewees expressed a reluctance for calling either surrogate or donor "mom", and therefore, they drew on a discourse where donors and surrogates are constructed as non-mothers, or not actual or real mothers. Still, the mother/mom construct was often used with a prefix, such as "surrogate mother", "biological mother", "host mom", "egg mom" or "belly mom". Ivan negotiated the word mom:

It came up in some discussions that someone used the word, er, "mom" about her [the surrogate] several times and in the end I had to correct that, because I felt that (Interviewer: Mm) it would be totally wrong, because she has, she has a host mom, she has an egg mom, you could say, but otherwise she has two dads and, in reality, no mom.

In the excerpt maternity is a complex issue which can be divided into different aspects. Ivan claimed that his child has a "host mom" and an "egg mom", but that 
neither of those are mothers "in reality". To actually be a mom, was thereby constructed as something other than giving birth or providing the oocyte. Rather, the fathers were depicted as the actual parents, "she has two dads". Dissociating the surrogate and egg donor from the mother concept may also have discursive benefits. The integrity of the two-father family is protected, as a non-mother need not be taken into account. While a "mother" living far away can be perceived as a loss for the child, a non-mother likely is not.

\section{Discussion}

Within critical discursive psychology talk is understood and analysed as action (Edley, 2001; Wiggins, 2017). When something is at stake for speakers, they will actively engage in rhetorical work in which their choices, values or features are presented as sound and reasonable. In the following discussion, we set out to make sense of the participants' constructions of surrogates and donors, in relation to culturally available understandings of surrogacy, egg donation and motherhood.

Two forms of narratives dominated the interviewees' talk about surrogates; they were constructed as close family members in warm and genuine relationships, and as active, strong and independent women. The image of strong, independent women who form long-lasting relations with the parents is recognizable as how surrogates often present themselves and their experiences of surrogacy (Teman, 2010; Teman \& Berend, 2018). Thus, surrogates and parents seem to have a mutual interest in this framing. The strong metaphors of kinship and close friendship hint that something was at stake for the interviewees - that it was important for them to describe the relationships as close, genuine and reciprocal.

In her ethnography on surrogacy in Israel, Teman (2010) showed how an emphasis on close relations and reciprocity effectively downplayed connotations of the underlying financial agreement. When surrogacy was framed as a favour or gift, it was simultaneously disconnected from images of exploitation. The emphasis on "loving being pregnant" and "wanting to do a good deed" has the rhetorical effect of covering financial motives and inequality. When the interviewees in the present study emphasized a reciprocal relation, this must be understood in relation to the ongoing debate in Sweden and elsewhere, in which surrogacy is constructed as exploitation, dehumanization and prostitution (e.g. Collmar, 2017; Ekis Ekman, 2010; Uppdrag granskning, 2018; Aström, 2011). For these fathers, rhetorical work was necessary to provide a counter-discourse of surrogacy, in which their own decisions were depicted as solid, ethical and genuine, and the relationship they had formed was loving and reciprocal.

The images of surrogates as vulnerable, exploited or as having only an instrumental function did emerge in the interviews. They were present in short glimpses, often in relation to the separation of infants from the surrogates. This finding echoes Teman's (2010) descriptions of parents' reactions to this separation. We argue that these short segments show that ethical considerations and doubts about what is right and wrong were to some extent part of the parents' experience, despite 
the otherwise positive framing. However, such narratives were difficult to articulate as they conflicted with the discourse of a strong independent woman, that was more desirable, or even necessary, for the interviewees to present.

Much less was said about the donors than the surrogates. While there are examples in the interviews in which the relationship to the donor was constructed as close and genuine, or in which the interviewees highlighted the donor's motive for donating eggs as important, they did not engage extensively in any rhetorical work to justify their utilization of donated oocytes. This could be understood in relation to the current Swedish situation, where egg donation is an established practice in public healthcare and a law passed in 2003 without much debate (Mägi \& Zimmerman, 2015). The technological procedure of hormonal simulation of ovaries and egg retrieval surgery under local anaesthesia is an established procedure in modern fertility care, but is not without risks of medical complications (e.g. Delvigne \& Rozenberg, 2002). To have a previously unrelated woman undergo the procedure was, not, however, generally problematized in the interviews. Rather, the involvement of an egg donor was often motivated by the interest of the surrogate in not "giving up" her own genetic child. Thus, the discourse of a vulnerable surrogate connects with the discourse of donors as instrumental providers of genetic material.

All but one couple had open donors, and all couples with more than one child had the same donor for all their children. This can be understood in relation to a dominant discourse in Sweden, where knowledge of one's genetic origin is constructed as a fundamental human right (Malmquist, Polski, \& Zetterqvist Nelson, 2017). Accordingly, anonymous gamete donation is prohibited by Swedish law. When the parents take turns in being the genetic parent in the same-sex couples, a genetic tie is constructed between the siblings through the donor. This practice can be understood in relation to a discourse where much emphasis is put on blood or genetic relations (e.g. Nordqvist, 2010; Schneider, 1980), which is echoed in the discourse of the donor as an instrumental provider of genetic material.

Most interviewees used the concept "mother/mom" ambiguously. When surrogates and/or egg donors were depicted as mothers, the construction could be understood as a normalization of the gay father family. In a heteronormative society, where gay fathers are often depicted as awkward or different (Andreasson \& Johansson, 2017; Zetterqvist Nelson, 2006), the presence of one or two mothers in the family narrative may have the rhetoric effect of showing that family as an "ordinary" one. However, most interviewees also did the rhetorical work of differentiating surrogates and egg donors from motherhood. Interestingly, this was generally done by using the concept "mother/mom" together with a range of prefixes, such as "belly mom", "carrier mother" or "egg mom". Anthropologist David Schneider (1980) showed in his work on American kinship how relatives in western cultures are understood as people related by "blood" (e.g. biogenetics) or by law or relationship (e.g. marriage). Biogenetically related people are generally understood as "real" relatives, whereas prefixes such as "foster", "adoptive" or "step" are used to mark that a similar relationship is formed without biogenetic bonds. The effect of such prefixes is that those relations are understood as less 
"real" compared to relations formed by biogenetics. The prefixes used by the interviewees in the present study did acknowledge a gestational or genetic bond between the surrogate/egg donor and the child. Rhetorically, however, these prefixes had a similar effect as the prefixes used to mark non-biological relations, i.e. they served to construct surrogates and donors as something different from ordinary, actual or real mothers. Biogenetic relations were constructed as less "real", compared to relations established through care.

The rhetorical separation of surrogates and donors from "real" mothers also disconnects them from normative ideas about motherhood. Because of a semantic closeness between motherhood and care (e.g. Berkowitz, 2011), the fathers might need to stress that their children have all the parents they need, that the children have not been abandoned, and are not lacking proper caregivers, despite not being cared for by a woman. According to Berkowitz (2011), gay fathers must construct and negotiate their parenthood in a context where primary parenting is most often done by mothers, and fathers are expected to play a more complementary role. Although the strong discourse on gender equality in Sweden has been described as beneficial for gay fathers (Andreasson \& Johannsson, 2017), our interviewees still seem to rhetorically relate to and dissociate from a discourse of the essential mother. Elsewhere, the disconnection of surrogacy from motherhood has also been shown to be prominent in surrogates' own narratives of their experience (Teman, 2010; Teman \& Berend, 2018). Thus, surrogates and parents seem to have a mutual interest in framing surrogates as non-mothers.

To conclude, we have shown how gay fathers depicted the reproductive labour done by women as they have carried pregnancies, given birth, and provided oocytes as donors. The gay fathers' rhetorical work presented surrogates as strong, independent women, committed to doing good deeds. At the same time, the gay fathers opposed the discourse of exploited, vulnerable surrogates. In comparison, little rhetoric work was done to justify egg donors' motives. Rather, egg donors were often depicted as instrumental providers of genetic material.

\section{Acknowledgements}

We wish to express our gratitude to Alexander Spånberg Ekholm for taking part in data collection and transcription, and to all parents participating in the study.

\section{Declaration of Conflicting Interests}

The author(s) declared no potential conflicts of interest with respect to the research, authorship, and/or publication of this article.

\section{Funding}

The author(s) disclosed receipt of the following financial support for the research, authorship, and/or publication of this article: The present work was funded by Forte (No 2017-00617).

\section{ORCID iD}

Anna Malmquist (D) https://orcid.org/0000-0002-9406-1976 


\section{Notes}

1. Surrogates and egg donors do not necessarily identify as women or refer to themselves with the pronouns "she" and "her". However, in our data, all interviewees referred to them as women.

2. The word "mamma" in the original Swedish has been translated as "mom" or "mother", depending on the context. The word "mamma" is broadly used in Swedish and largely covers both the English words "mom" and "mother".

\section{References}

Andreasson, J., \& Johansson, T. (2017). It all starts now! Gay men and fatherhood in Sweden. Journal of GLBT Family Studies, 13, 478-497.

Arvidsson, A., Johnsdotter, S., \& Essén, B. (2015). Views of Swedish commissioning parents relating to the exploitation discourse in using transnational surrogacy. PLOS ONE, 10(5), $1-12$.

Arvidsson, A., Johnsdotter, S., Emmelin, M., \& Essén, B. (2019). Being questioned as parents: An interview study with Swedish commissioning parents using transnational surrogacy. Reproductive BioMedicine and Society Online, 8, 23-31.

Åström, G. (2011). Surrogacy motherhood: A global trade with women's bodies: Policy paper. Stockholm, Sweden: Sveriges Kvinnolobby. Retrieved from: http://sverigeskvinnolobby. se/wp-content/uploads/2013/08/POLICY-PAPER-SURROGACY-MOTHERHOOD.pdf

Berkowitz, D. (2011). Maternal instincts, biological clocks, and soccer moms: Gay men's parenting and family narratives. Symbolic Interaction, 34(4), 514-535.

Blake, L., Carone, N., Raffanello, E., Slutsky, J., Ehrhardt, A., \& Golombok, S. (2017). Gay fathers' motivations for and feelings about surrogacy as a path to parenthood. Human Reproduction 32(4), 860-867.

Blake, L., Carone, N., Slutsky, J., Raffanello, E., Ehrhardt, A., \& Golombok, S. (2016). Gay father surrogacy families: Relationships with surrogates and egg donors and parental disclosure of children's origins. Fertility and Sterility, 106(6), 1503-1509.

Carneiro, F., Tasker, F., Salinas-Quiroz, F., Leal, I., \& Costa, P. (2017). Are the fathers alright? A systematic and critical review of studies on gay and bisexual fatherhood. Frontiers in Psychology, 8, article no 1636.

Carone, N., Baiocco, R., Manzi, D., Antoniucci, C., Caricato, V., Pagliarulo, E., \& Lingiardi, V. (2018). Surrogacy families headed by gay men: Relationships with surrogates and egg donors, fathers' decisions over disclosure and children's views on their surrogacy origins. Human Reproduction, 33(2), 248-257.

Collmar, L. (2017). Surrogatmamman i Tbilisi. [The surrogate mother in Tiblisi]. Stockholm, Sweden: Sveriges radio. Retrieved from https://sverigesradio.se/sida/avsnitt/904277?pro gramid $=909$

De Melo-Martín, I., Rubin, L., \& Cholst, I. (2018). "I want us to be a normal family": Toward an understanding of the functions of anonymity among U.S. oocyte donors and recipients, AJOB Empirical Bioethics, 9(4), 235-251.

Delvigne, A., \& Rozenberg, S. (2002). Epidemiology and prevention of ovarian hyperstimulation syndrome (OHSS): A review. Human Reproduction Update, 8(6), 559-577.

Edley, N. (2001). Analysing masculinity: Interpretative repertoires, ideological dilemmas and subject positions. In M. Wetherell, S. Taylor, \& S. Yates (Eds.), Discourse as data: A guide for analysis (pp. 189-228). Milton Keynes, UK: Open University. 
Ekis Ekman, K. (2010). Varat och varan: Prostitution, surrogatmödraskap och den delade människan. [Being and being bought: Prostitution, surrogacy and the split self]. Stockholm, Sweden: Leopard Förlag.

Humbyrd, C. (2009). Fair trade international surrogacy. Bioethics, 9(3), 111-118.

Höjerström, S. (2018). "Det finns två föräldrar och det är papporna, men så finns lite personer runt omkring": En diskursanalytisk studie $i$ hur manliga samkönade föräldrapar framställer bäraren och äggdonatorn $i$ samband med värdgraviditet. ["There are two parents and that's the dads, but there's also some other people": A discourse analysis of how gay fathers construct the surrogate and the egg donor in surrogacy.] Master thesis, Linköping University, Sweden.

Jadva, V., Freeman, T., Kramer, W., \& Golombok, S (2010). Sperm and oocyte donors' experiences of anonymous donation and their subsequent contact with their donor offspring. Human Reproduction, 26(3), 638-645.

Jadva, V., Gamble, N., Prosser, H., \& Imrie, S. (2019). Parents' relationship with their surrogate in cross-border and domestic surrogacy arrangements: Comparisons by sexual orientation and location. Fertility \& Sterility, 111(3), 562-570.

Johansson Agnafors, M. (2014). The harm argument against surrogacy revisited: Two versions not to forget. Medicine, Health Care and Philosophy, 17(3), 357-363.

Malmquist, A. (2015). Pride and prejudice: Lesbian families in contemporary Sweden. Doctoral thesis, Linköping University, Sweden.

Malmquist, A. (2016). Lesbiska småbarnsföräldrar: Utmaningar $i$ en tid av möjligheter. [Lesbian parents with young children: Challenges in a time of possibilities]. Gothenburg, Sweden: Makadam.

Malmquist, A., \& Spånberg Ekholm, A. (2020). Swedish gay men's pursuit of fatherhood: Legal obstacles and strategies for coping with them. Lambda Nordica, 24(2-3), 53-80.

Malmquist, A., Polski, A., \& Zetterqvist Nelson, K. (2017). No one of importance: Mothers in lesbian relations talk about permanently anonymous sperm donors. In: A. Sparrman, A. Westerling, J. Lind, \& K-I Dannesbo (Eds.), Doing good parenthood (pp. 29-40). Hampshire, UK: Palgrave Macmillan.

Mamo, L. (2018). Queering reproduction in transnational bio-economies. Reproductive Biomedicine \& Society Online, 7, 24-32.

Mägi, E., \& Zimmerman, L. (2015). Stjärnfamiljsjuridik: Svensk lagstiftning ur ett normkritiskt perspektiv. [Queer family law: A norm critical perspective on Swedish legislation]. Malmö, Sweden: Gleerups Utbildning AB.

Nordqvist, P. (2010). Out of sight, out of mind: Family resemblances in lesbian donor conception. Sociology, 44(6), 1128-1144.

Schneider, D. (1980). American kinship: A cultural account. Chicago, IL: University of Chicago Press.

SOU 2016:11 Olika vägar till föräldraskap [Different paths to parenthood]. Stockholm, Sweden: Wolters Kluwer.

Stuvøy, I. (2018). Troublesome reproduction: Surrogacy under scrutiny. Reproductive Biomedicine \& Society Online, 7, 33-43.

Sydsjö, G., Skoog Svanberg, A., \& Lampic, C. (2019). Cross-border surrogacy: Experiences of heterosexual and gay parents in Sweden. Acta Obstetricia et Gynecologica Scandinavica 98(1), 68-76.

Söderström-Anttila, V., Wennerholm, U-B., Loft, A., Pinborg, A, Aittomäki, K., Romundstad, B., \& Bergh, C. (2016). Surrogacy: Outcomes for surrogate mothers, 
children and the resulting families: A systematic review. Human Reproduction Update, 22(2), 260-276.

Teman, E. (2010). Birthing a mother: The surrogate body and the pregnant self. Berkeley: University of California Press.

Teman, E., \& Berend, Z. (2018). Surrogate non-motherhood: Israeli and US surrogates speak about kinship and parenthood. Anthropology and Medicine, 25(3), 296-310.

Thompson, C. (2005). Making parents: The ontological choreography of reproductive technologies. Cambridge, MA: MIT Press.

Uppdrag granskning. (2018). De nya surrogatmödrarna. [The new surrogate mothers]. Stockholm, Sweden: Sveriges television. Retrieved from https://www.svtplay.se/video/ 19352859/uppdrag-granskning/uppdrag-granskning-sasong-19-de-nya-surrogatmo drarna?start $=$ auto\&tab $=2018$

Ventura, R., Rodríguez-Polo, X., \& Roca-Cuberes, C. (2019). "Wealthy gay couples buying babies produced in India by poor womb-women": Audience interpretations of transnational surrogacy in TV news. Journal of Homosexuality 66(5), 609-634.

Wiggins, S. (2017). Discursive psychology: Theory, method and applications. London, UK: SAGE.

Wilkinson, S. (2003). The exploitation argument against commercial surrogacy. Bioethics, $17(2), 169-187$.

Zettergren, S. (2011). FÖR: Ulrika Westerlund. [PRO: Ulrika Westerlund]. Aftonbladet, feb 25 2011. Retrieved from: https://www.aftonbladet.se/relationer/a/KvP8zE/for-ulrikawesterlund

Zetterqvist Nelson, K. (2006). Att vara pappa i homofamiljer: Berättelser om barn, mammor och familjeliv. [Being a father in a gay family: Narratives about children, mothers and family life]. Socialvetenskaplig Tidskrift, 13, 66-86.

Ziv, I., \& Freund-Eschar, Y. (2015). The pregnancy experience of gay couples expecting a child through overseas surrogacy. The Family Journal, 23(2), 158-166.

\section{Author Biographies}

Anna Malmquist (PhD) is an associate professor in social psychology at Linköping University, Sweden. Her research has a main focus on LGBT families. Her doctoral thesis, Pride and prejudice: Lesbian families in contemporary Sweden (2015), concerned lesbian motherhood. Presently she leads a research project on gay fatherhood in Sweden, alongside with a project on fear of childbirth in lesbian and bisexual women, and transgender people. Malmquist has also co-edited the first book in LGBTQ psychology published in Swedish.

Sonja Höjerström is a psychologist who graduated from Linköping University, Sweden, in spring 2018. Her master's thesis, “"Det finns två föräldrar och det är papporna, men så finns lite personer runt omkring": En diskursanalytisk studie i hur manliga samkönade föräldrar framställer bäraren och äggdonatorn i samband med värdgraviditet" [There are two parents and that's the dads, but there's also some other people: A discourse analysis of how gay fathers construct the surrogate and the egg donor in surrogacy] (2018), was a discourse analysis of how gay fathers construct the surrogate and the egg donor in surrogacy. 